\title{
Spatial Perspectives on Voluntarism in Learning Disability Services in Ireland
}

\author{
ANDREW POWER \\ Researcher, Centre for Disability Law and Policy, NUI Galway, Ireland \\ email: andrew.power@nuigalway.ie
}

\begin{abstract}
Voluntarism has moved to the centre of most western neo-liberal governments' focus in terms of welfare delivery. At the same time, very little of the social policy literature has identified specific historical, cultural and political contexts of place in shaping the particular form of voluntarism and the scale at which it takes place in a country. In order to address policy-related issues of the voluntary sector, a geographical perspective focusing on these local contexts can be very useful in unpacking how the sector can exist across regional and local scales. This article explores the rise of voluntarism in adult learning disability services in Ireland. Ireland experienced the 'community turn' much earlier than most Western states, in that the state advocated a 'hands-off' approach in learning disability services from the outset. It uses data from 40 interviews with local health agencies, voluntary organisations and informal carers. It critically examines the complex geographical factors that have contributed to the particular form of voluntarism that has evolved, thus demonstrating that understanding levels of voluntary activity requires attention to local circumstances.
\end{abstract}

\section{Introduction}

The increasing significance of the voluntary sector in welfare provision in many neo-liberal states is well documented in a wide body of research in both social policy and the social sciences, and has seen an upsurge in policy initiatives in the UK with New Labour's 'third way' (Macmillan and Townsend, 2006) and in the US with the White House Office of Faith-based and Community Initiatives (Sherman, 2000). Both involve a clearer and deeper relationship with voluntary organisations. The sector has thus grown remarkably, expanding its activities and geographic reach (Wolch, 2006).

To reflect these changes, there has been a wealth of literature in political and social science. This work has begun to elaborate more sophisticated explanations of the key themes on voluntarism, including the changing political context of voluntary activity (see Taylor and Bassi, 1998), the professionalisation of the voluntary sector (see Wyatt, 2002) and the competitive nature of the contracting culture (Mackintosh, 2000). The research is also now focusing on specific types 
of voluntary organisations, including community groups, black and minority ethnic associations and 'faith-based organisations' (Bacon, 2006).

However, it is also important to understand how the voluntary sector is shaped by place and particularly how this shifts over time due to cultural and political influences. With some exceptions by sociologists/public policy analysts (Anheier and Salamon, 1999; Milligan and Fyfe, 2004; Wolch, 1989; Grønbjerg and Paarlberg, 2001; Pfau-Effinger, 2005), the spatial context of voluntarism has been largely ignored. Typologies of government-voluntary sector relations mostly categorise nation-level situations, without any reference to the spatial context, and omit consideration of intra-national differences (Vincent and Harrow, 2005). Understanding levels of welfare activity requires attention to local circumstances, as argued by Fernández et al. (2007). There has been a developing interest by geographers in the role, governance and spatial organisation of voluntary services in providing a 'third sector'.

In order to highlight the importance of space, we must understand how the geography of voluntarism is influenced by the historical, cultural and political processes acting in a place. A geographical perspective based on these specific contextual factors can contribute to a wider understanding of the more complex interplay between people and places that underpins why different forms of voluntarism develop in different places at different times. Such an approach, according to Kitchin and Wilton (2003), also lets us see the scale at which the political structures of voluntarism operate and how these shift over time.

This article aims to illustrate this through a case study of the adult learning disability voluntary (LDV) sector in Ireland. This is taken to mean the entire range of voluntary organisations involved in the area of learning disability service provision for adults (18-30) with learning disability (LD) and their families. A learning disability is characterised by intellectual functioning being significantly below average, having difficulties with everyday life skills and the condition is present from early childhood (NAMHI, 2004). Due to the generic nature of the impairment, the LDV sector is characterised by a plethora of different groups from local 'grass-roots' organisations, including parents' groups, advocacy and occupational training agencies to larger 'corporatist' welfare bodies at the national scale, such as rights recognition groups and national caregiver support bodies. It thus represents the whole spectrum of voluntary activity, with services ranging from tangible provision, such as domiciliary based respite and personal care, practical home support (for example, meals provision and home maintenance tasks), daycare centres, transport schemes, to non-tangible services, such as support, information and campaigning groups (Milligan, 2001).

In terms of Irish data on voluntarism in LD service provision, the most comprehensive source of data is the LDV Directory of Services by the National Association for People with LD, Inclusion Ireland (NAMHI, 2003). According to their directory, there are $237 \mathrm{LDV}$ centres providing services and support to 
people with LD in Ireland. While these data do not map provision against service need, they do offer an overall picture of the type and size of organisations that exist and where they are located. Of particular note is the extent of uniquely different providers ( 58 per cent) specific to their locale in almost every region of the country. Within this, some clear clusters and gaps are evident across Ireland, with strong patterns of provision in the Greater Dublin Area and its commuting hinterlands, as well as around some of the other large towns and cities. While this is to be expected, there are some noticeable gaps in Dublin on the one hand, and large service clusters in more rural parts of the country on the other, especially in the north west and south east.

While these offer a sense of the wider picture, this article is concerned with understanding local perspectives on the factors contributing to the particular development and workings of LD care services. Historically, the LDV sector in Ireland can be seen to be unique, given the role of the Catholic Church in shaping cultural expectations of voluntarism and the state's reluctance to interfere with the family. It is these specific aspects of voluntary sector development that are addressed within this article.

This is done in three ways. First, the article briefly outlines some of the ways in which geographers have contributed to a wider understanding of voluntary sector development. Second, building on this work, the article draws on material from my own completed research in Ireland, to examine the unique historical, cultural and political context at the national scale. Of particular concern is how and why the LDV sector geographies have changed over time. Finally, it explores the spatial issues that exist at the intra-national scale across Ireland as a result of this particular historical development.

\section{Geographic perspectives on the voluntary sector}

As mentioned, there has been a wealth of literature in political and social science on the voluntary sector. As widely discussed within this literature, the voluntary sector in the broadest of terms is perceived as an alternative to state bureaucracy and professional elitism; and a space between government and market (Powell and Guerin, 1997). It is characterised by a diversity in sources of funding, services, size, internal structure and autonomy (Anheier and Salamon, 1999). Groups range across a spectrum from non-profit-making bodies with paid employees answerable to a voluntary committee, to those who are philanthropic in the purest sense (Cochrane and Gerwitz, 2000). Geographically, those operating at the local level can also be differentiated by their organisational structure: that is, those who are locally based and independent of any hierarchical structure; those who are locally based but affiliated to a national body; and those who are essentially 'satellite' organisations answerable to a national body (Milligan, 2001). 
Although the geography of voluntarism is still largely undeveloped, a body of work has begun to emerge in the last decade or so that examines, in various ways, the interplay between politics, place and voluntarism (Milligan and Fyfe, 2004). In particular, geographers have demonstrated the extent to which the local historical, cultural and political context plays a part in helping to understand how voluntarism varies across scale, from national, regional to local levels (Wolch, 2006). Notable areas of activity include such topics as AIDS (Brown, 1997), community governance (Macmillan and Townsend, 2006), ethnicity (Lalich, 2006), community safety and mental health (Bondi, 2004), frail older people (Milligan, 2001), reforming public health (Barnett and Barnett, 2006) and faithbased organisations (Bacon, 2006).

In a locational sense, geographic research highlights the interdependence of the voluntary sector with the state at various spatial scales and the uneven spatial patterns of non-profit sector coverage and resources (Wolch, 2006). The geography of health and welfare provision is inevitably tied up with issues of resource allocation, priority setting or 'rationing' of services. Government constraints on health care expenditure mean that they cannot provide all the care a state might wish and therefore decisions have to be made about the nature and range of services to provide. These are questions of a geographical as well as an economic, political and managerial nature, since 'such services will have to be provided somewhere' (Gatrell, 2002: 136, emphasis added).

To tease these issues apart, geographers generally focus on three key themes: space, place and political context, as stated by Milligan and Fyfe (2004). All three are heavily inter-related as a result of the many actors involved. Under the first theme, the tensions between efficiency and effectiveness essentially create the spatial properties of health care resources (that is, where the providers are and why they are there). The key question is whether geographical 'variation' in the provision and use of health services also represents 'inequity' (Gatrell, 2002). This is the same question for the voluntary sector; however, explanations for spatial patterns tend to be focused in the geographical literature on differences in local cultures and the historical development of philanthropy within particular places over time (Bryson et al., 2002). The second theme is revealed at a local scale, where specific place-based patterns can be identified. The organic and flexible nature of the voluntary sector has often meant its service catchments can become more decentralised and inconsistent, responding to localised needs, or being prompted differently by active individuals (Brown, 1997). This gives rise to place-specific variations where particular agglomerations of voluntary groups occur in reaction to local, place-based needs.

Beyond the basic relationship between consumer/user and provider, however, many actors become involved in shaping the equity in the provision or availability of voluntary and state support. This is where political context becomes crucial to understanding the geography of voluntarism: that is, how 
the state conceptualises and engages with the voluntary sector. Institutions that manage the finances for health care providers can facilitate or hinder the provision of voluntary services, and government is usually called upon to set policy and adjudicate conflicts between all groups representing the national interest (Gatrell, 2002).

The dialectic of state-voluntary sector interdependence in social welfare, and its impact on service provision, has been the subject of significant debate, not only within geography but also more widely across the social sciences. It is clear that work in this area is making a significant contribution to wider debates about how, where and why voluntary activity in health and welfare develops differently in particular places at particular times (Milligan, 2007). While researchers have begun to elaborate more sophisticated explanations for the overall trajectory of developments in voluntarism, research on local patterns has been relatively limited in the social policy literature, despite considerable variations in the introduction, take-up and level of such areas of policy as direct payments (Fernández et al., 2007). Hence, they often fail to address the more complex interplay between people and places that emphasises why different forms of voluntarism develop in different places.

\section{Methodology}

The study takes as its locus the regional jurisdictional scale of the Health Service Executive Areas (HSEAs) to examine the dynamics of interdependency between voluntary and state sectors across space. These structures, which until 1 January 2005 were known as Health Boards, have been replaced by the newly created HSEAs, which, for the current interim period, effectively replicate the old Health Board areas. Interviews were carried out with key informants from four health authority areas: the Northern Area Health Board, the South Western Area Health Board, the Western Health Board and the Midland Health Board. These Health Board regions were chosen in order to get a cross-section of regional policy-making from the east through to the west of the country. The interview questions focused on what services were provided, how decisions were made on the particular service provision, and what were the main service gaps of which they were aware.

In terms of the voluntary sector, 11 interviews were carried out with key representatives from the voluntary sector, including: Carers Association (national and regional), Inclusion Ireland (formerly NAMHI, the National Association for Mentally Handicapped in Ireland), Alzheimer Society, Age Action, CaringforCarers, Care Alliance, KARE (Kildare Association of Parents \& Friends of Handicapped People) (education and advocacy divisions), Fingal Awareness (FADE) and Remember Us (Dublin LD groups). Two separate themes were addressed in the interviews with voluntary groups. First, in relation to their 
advocacy role, the questions related to carers and LD issues and concerns. Second, in terms of their role as service provider, the questions related to their relationship with Health Boards and how they addressed service gaps.

In addition, 25 interviews were undertaken with people who identified themselves as family caregivers looking after a young adult with LD (18-30) in North County Dublin and County Kildare (suburban hinterland outside Dublin). The majority of carers in the study are women, thus reflecting the gender divide in informal caregiving (Central Statistics Office, 2004). The predominant impairment of the care recipient is Down Syndrome (followed by moderate autism), which reflects the fact that this is the most common form of LD. Two themes were addressed in the interviews: the first involved a group of questions relating to their socio-spatial experiences of caregiving for young adults with LD in the home and in public; the second focused on their experiences and perceptions of accessing and using services.

This particular article draws on the interview themes relating specifically to the operating of LDV services, gaps in service, and issues of access from the three perspectives. The interviews with Health Boards were valuable in gaining an account of their practices, roles, relationships with providers and service gaps. The interviews with voluntary groups were useful in gaining the perspective of their interaction with Health Boards as well as their viewpoint on the overall landscape of care. Finally, the carers' views were useful for cross-checking and confirming data from the other perspectives about services. While most carers shared the same perspectives as voluntary bodies regarding statutory services, they were at the same time aware of shortcomings of the local focus of welfare services.

\section{Development of LDV provision in Ireland}

This section examines the unique development of voluntarism in Irish LD service provision. Present-day Ireland is almost incomprehensible in relation to its past history of deprivation, given the impact of its extraordinary period of growth (Meade, 2005). However, in terms of the state-voluntary sector mix, Inclusion Ireland has estimated that 80 per cent of LD services are provided by voluntary associations (although largely funded by Health Service Executives). Within this sector, generally, organisations provide a multitude of roles and are relied on heavily by the HSEAs. This is due to the socio-cultural context of Ireland, in particular the early strength of the Roman Catholic Church and the government's particular method of establishing community care.

\section{Role of the Church}

First, the Roman Catholic Church has been hugely influential in Irish politics. The Irish state, from the outset (1922), was influenced and reliant on the Catholic 
Church for both political support and for welfare and education provision. The Church was able to capitalise upon aspirations for Irish nationhood due to the high rates of Catholic followers. According to McLaughlin (1993), the Church provided the institutional links between the new political, economic and social elites and the masses.

The religious-based organisations tended to emphasise charitable principles and the duty of the rich to help the needy. A 1931 Papal Encyclical 'Quadragesimo Anno' espoused the principle of 'subsidiarity' as a means of circumscribing state encroachment on voluntary welfare and charity arrangements (O’Leary, 2000). This held that responsibility for social issues lay with the basic societal units, such as the family and the parish, and only when these were seen to fail could the state step in as a last resort. The Encyclical stated that: 'It is an injustice and at the same time a great evil and disturbance of right order to assign to a greater and higher association what lesser and subordinate organisations can do' (quoted in McLaughlin, 1993: 206). The state was viewed by the Church as having a functional role of ensuring social order; it should refrain from intervening in social affairs. As a consequence, state activity in the field of social welfare was relatively tardy in comparison with England (Donoghue et al., 1999).

The implications of this in the LD sector have been a greater historical legacy of charitable giving and local altruism as a means of addressing welfare needs of local communities in Ireland than elsewhere. This concept of charity has remained a strong theme and was a major factor in the particular development of Irish local voluntarism. Indeed, this 'doing good' aspect coloured secular involvement, particularly in the social welfare field. As a consequence, Ireland saw a growth of grass-roots organisations, alongside the religious institutions, in LD support, whose motivation lay in a growing dissatisfaction with the effectiveness of state responses to supporting people with disabilities across the country (McLaughlin, 1993). People with LD had to therefore depend on being supported by religious asylums or local parents groups:

Well, there would have been large religious organisations, which were providing sort of education and other residential services and you know, there were large institutions where people with learning disabilities were sent away to, if you like, and that was the ethos at the time. And then you had grass-roots local organisations, that built up from be it parents, or just local initiatives, or people interested in coming together, then they moved on to sort of get more funding, and trying to fundraise actually - that's really how a lot of them started up, as voluntary charitable sort of groups. (Inclusion Ireland)

This resulted in an organic, small-scale and predominantly local voluntary sector growth across the country. All political parties broadly supported this type of voluntarism and, unlike in the UK, there was little public debate about an alternative approach. Families who chose to look after their child with LD at home had to rely on parents' groups and underfunded charities for support. Family 
services were regarded as outside the remit of government as the traditional male breadwinner role and female carer role were enshrined in the Constitution (McLaughlin, 1993).

\section{Era of de-institutionalisation}

Shortly after this, there was an ideological shift from institutional to deinstitutional care and a growth of grass-roots organisations dissatisfied with the status quo. The state's favouring of the provision of community-based services through religious orders and local voluntary bodies continued in response to deinstitutionalisation of people with LD. The first sign of change was the Health Act (1953) which introduced Section 65 grants for any Church or voluntary body in the community providing services 'similar or ancillary' to their own. This marked the beginning of a new relationship between statutory and local LDV groups. In practice, however, statutory services could be more accurately described as complementary, with voluntary organisations providing, in many cases, essential services (Donoghue, 2002).

De-institutionalisation increasingly began to appear in government rhetoric in the 1960s, with greater pressure to move away from care in large institutional environments, due to increased concerns for civil rights. However, the government, aware of the extent of voluntary services across Ireland, published the White Paper 'The Problem of the Mentally Handicapped' (Department of Health, 1960), which favoured an extension of the activities of the voluntary organisations into the community. The later report of the commission of Inquiry on Mental Handicap (Government of Ireland, 1965) mirrored the White Paper by favouring the provision of community-based services through religious orders and voluntary bodies (Quin and Redmond, 1996). This policy decision had a considerable impact on Irish service provision for people with LD. Local groups around the country (for example, KARE) were getting more organised, providing local services, such as schooling, adult occupation training and respite services. The government therefore recognised that these grass-roots organisations were the leading agents in advancing best practice.

In the 1970s, the state introduced legislation that saw a shift in providers away from the Church and towards this burgeoning local 'lay' voluntary sector. The Health Act (1970), which has been deemed the principal Act governing health care in Ireland, firstly continued to provide funding to voluntary activity and, secondly, made sure that the state's new social services and home help did not interrupt voluntary activity, especially in the area of disability services, preferring to focus on the presence of drug abuse and child protection services (Walsh, 1999). In the first case, section 26 of the Act meant continued support for voluntary activity in similarly loose terms. However, most voluntary groups have since continued to apply for Section 65 grants from the earlier legislation. 
In the second case, access to the home help service has been at the discretion of HSEAs, with many preferring to use the voluntary sector:

For [our] Area health board you can basically say that the home help service is provided on a voluntary basis in that there are committees throughout the whole region that we fund through what we call Section 65 grants. So what basically happens is there are local committees and they come to us and they basically look for us to give them money. (HSEA representative)

The development of home help has been constrained by the absence of an adequate legal basis, appropriate funding or agreed national quality standards (Haslett et al., 1998), which was typified during the study when all carers' home help hours within one health board region had been halved. This ad hoc development of statutory services and on-going support for local voluntarism has been typical in Ireland's history of LD service provision.

\section{Irish LDV provision: an intra-national perspective}

While the factors mentioned in the previous section demonstrated the reasons why the voluntary sector in the area of LD service provision developed in such a fashion, this section examines the specific outcomes of this historical, cultural and political context on the ground. Despite the successes which the local voluntary sector has achieved in being able to target the needs of people with LD directly, these successes in and of themselves have created a number of challenges. In particular, these challenges have been in relation to the uneven geography of voluntarism across Ireland. It is therefore important to foreground the local scale with the historical context, as the main characteristics of the sector have been largely shaped by early Irish conceptions of the roles and responsibilities of voluntarism.

\section{Planning and local politics}

While the government has continually 'recognised' the LDV sector, it has at the same time failed to set up a national spatial strategy for planning LD voluntarism. This means that at the regional and local level, there has been no distinct geographic plan that aims to structure voluntary home care across scale. The lack of legislation and mandatory provision has meant that community care can appear quite different in different parts of the country:

There is a huge amount of inconsistency. We could take you to families living only a couple of miles from each other, with the River Shannon in the middle. And eh... the River Shannon seems to have a huge effect on services... And I think that can depend an awful lot on personalities within health boards. (Carers Association)

The absence until January 2005 of any organisation responsible for managing the health service as a unified national system (now under the remit of the Health Service Executive) has left behind a legacy where the impact of human 
agency and the cult of the individual have been ubiquitous in community care, where politically strong advocates have been instrumental in promoting the development of a particular service. The lack of mandatory requirements in the planning of community care has meant differences in approach exhibited by local HSEAs with different political leanings, which can result in the creation of areas of 'winners' and 'losers':

In the [other] health board area, they seem to look after their carers an awful lot better than they do up this side. I mean all those Carers' weekends away. I pay for all my weekends, when they're all funded to go. It depends on where you live. The [local] Health Board, they're financially embarrassed at the moment, they've halved the home help hours. I know a lot of people from the West from the different Carers meetings and they get great respite care. (Carer R4)

HSEAs have not historically put much emphasis on LD domiciliary services and have left them largely to the voluntary sector, preferring to concentrate on residential care provision. When coupled with the organic nature of the voluntary sector, community care service catchments have become more decentralised and inconsistent, responding to localised needs, or being prompted differently by active individuals. Representation has thus been along geographical or user category lines and only rarely both (Donoghue, 1998).

According to the voluntary organisations interviewed, within the medley of associations and groups there is a lack of shared knowledge between service providers, and from a geographic point of view it appears that service provision is often ad hoc and poorly integrated across the country:

Developing relationships with other voluntary organisations - it's an area I think that probably hasn't been that well developed in the past. I think it's something that is going to be a major focus over the next while, and I certainly think that [due to] the nature of the voluntary sector, that there are a lot of voluntary organisations that just got out there and did their own thing. (Carers Association)

While there have been some integrated initiatives in child services, it still remains fragmented for adult services. In particular, those organisations not concerned with influencing the wider policy process have been intent on focusing on their local services, not the national picture. Furthermore, even some 'national' voluntary agencies are territorially designed to meet the very specific needs of particular places, such as CaringforCarers, a 'national' support service based in County Clare. While voluntary sector advocacy elsewhere has generally focused on the national scale to effect change, such as in the UK and Canada (Kitchin and Wilton, 2003), in Ireland the sector appears to be unique in terms of its focus on the local.

The focus on the local has largely been a result of Ireland's history as a British colony, when power was centralised in Dublin. The political landscape has since remained dominated by local clientelism as a mode of governance. The system of proportional representation supports four or five TDs (Irish Ministers) 
representing each constituency, with one of the highest representative ratios in Europe between each TD and the public (approximately 1:8,00o) (Breathnach, 1992). This allows the public greater access to their political representatives and the ability to force constituency TDs to compete against one another (Kitchin and Wilton, 2003). Any change to this scenario remains unlikely, as it is in politicians' interest to foster clientelism, as local government reform would erode their power. This focus on the local political agent aggravated many carers and voluntary organisations alike, as they often played gatekeepers and arranged the allocation of services to users. While many parents were forced to access their services through this means, they disagreed with the fairness of this method of delivering services:

It's just the way it works. People say we haven't got a good TD for our area. There's no point in voting for him because he won't do anything for you, rather than looking at the whole country, and saying, 'We all live in this bloody island, and a Down's Syndrome child shouldn't be treated any different in [Sligo] than in [Skerries].' But they are. (Carer R21)

As a result of clientelism the LDV movement is highly fragmented, and has thus generally been organised at the local, constituency scale, at which change can be effected. Given the importance of the local scale in Irish politics, grass-roots groups, such as KARE, the Newbridge Access Group (NAG) and Fingal Awareness of Disability and Equality (FADE), have been both unable and unwilling to 'jump scale' and lobby at the national level, preferring to use the clientelist system, targeting specific local politicians to effect change (Kitchin and Wilton, 2003).

While attempts have been made by disability rights bodies, such as People with Disabilities Ireland Ltd, to jump to the national scale, they have been reminded that their very survival is dependent on the benevolence of central government. In relation to their attempts at co-ordinating and enlarging the sector's role and authority, according to Meade (2005) the state has mutated from generous benefactor to stern assessor within state-voluntary partnerships and has reminded community organisations of their own vulnerability. Consequently, these community groups have by and large been unwilling to 'jump scale' (Kitchin and Wilton, 2003) to effect change at the national level as they have been afraid to 'rock the boat', because they feel they might not get the funding.

\section{Funding: grants and charity fundraising}

Another consequence of the particular cultural and political history of Ireland has been the ad hoc funding of the voluntary sector. Of particular note here is the extent with which HSEAs allocate tasks and funding to the voluntary organisations. In some HSEAs, there is an obvious commitment to provide community services formally, instead of through the use of voluntary agencies. One traditional HSEA situated in a large rural area had a commitment to public service provision, while a more conservative metropolitan HSEA was committed 
to policies centred on the dismantling of public provision in favour of contracting out to the voluntary sector. This has profound geographical consequences on the appearance of the landscape of care at a local level across Ireland:

Well I know definitely the [Blue Area] Health Board is progressive in the sense that it itself provides a lot of the services, rather than having the voluntary organisations doing it for them, and the services that they do provide are very professional in the sense that they develop self-advocacy and they're really moving on things. (Inclusion Ireland)

On the other hand, in areas where a HSEA is deemed to be less progressive, the voluntary sector has, perhaps by necessity, become a much stronger provider of services. Due to the lack of prior statutory coverage of community care services in these areas, community care for the HSEAs are generally still based on the provision of residential services, where voluntary groups are heavily relied upon for domiciliary care support:

You have the [Green Area] Health Board who has two or three residential services who would provide for a couple of hundred people. And their services are dire. I mean some of them are the worst in the country. And again because there is no funding prioritised, the Health Board are plodding along, while you have voluntary organisations in the same Health Board area doing wonderful things. (Inclusion Ireland)

While these different cases give rise to a different landscape of care for people with LD, in both of these cases, however, there is a lack of emphasis on any national quality standards or a definition of a particular set of 'core services'. The development of 'core services' would have implied the establishment of clear criteria for their provision and eligibility, and the provision of earmarked funding for them (DFI, 2002). According to Donnelly-Cox and O'Regan, the vagaries of the statutory-voluntary relationship in Ireland have meant the sector has generally been regarded as 'loosely defined and lightly regulated' (1998: 1). As a result, the coverage of LDV services across scale in Ireland is largely based on localised needs with little allegiance to places outside their remit.

Consequently, while the issues of state sector contracting have had a longer history in Ireland, in comparison with the UK, for example, the reality is that formal contractual arrangements are still in the negotiation stage (DonnellyCox et al., 2001). A White Paper, Supporting Voluntary Activity (DSCFA, 2000), has attempted to address the statutory-voluntary relationship and lay out some principles for the future operation of the relationship. However, despite the longestablished tradition of voluntary action in Irish society, there still remains a much looser funding arrangement with the voluntary sector at the local scale.

A major reason for funding and contractual arrangements remaining looser than elsewhere is the long history of deprivation in Ireland. Government cutbacks throughout the 1980 s and early 1990 os were to have a detrimental effect on voluntary sector operations, with the government being somewhat ambivalent to the sector and reluctant to enter into formal contractual agreements (Donoghue, 
1998). Today, despite getting funding under section 65 grants from HSEAs, many voluntary service providers still rely very heavily on charity fundraising. Even some large national organisations providing essential services for people with LD must rely on their own fundraising. Down Syndrome Ireland is a primary example: it provides family support, social and education services, and disseminates information, yet at the local level almost all funding for branches comes from fundraising. To show the extent of fundraising, the Comparative Nonprofit Sector Project found when public sector sources of income are viewed in comparison with cash from other sources, they are almost matched by funding from private sources, which is principally income from individuals (44.2 per cent of all income to social services) (Salamon et al., 1998). It appears that individual giving is higher in Ireland than in other Western European countries (ibid.), perhaps due to the long-standing Catholic notion of charity.

Even though much of the Church's power has waned, its charitable legacy is still evident in the name and ethos of many disability and care-giving bodies. According to the Directory of LDV services, 50 out of 237 LDV centres, based all over the country, are still church-affiliated, making up 21 per cent of the total (NAMHI, 2003). While the direct involvement of religious orders in these organisations is in significant decline, it is still important for many lay volunteers, as discovered by Geoghegan and Powell (2006). As the mission statement of Crosscare, a carer agency in Ireland, states:

Drawing inspiration and guidance from the Gospel of Jesus Christ and from the social teachings of the Catholic Church - our mission in Crosscare is to serve the needs of the poor and marginalised. (Crosscare, 2007)

For some, however, the construction of care and support as an act of benevolence to dependent and needy subjects is anathema. Disability lobby groups elsewhere have resisted any association with religious and other such charities (Oliver and Barnes, 1998). Such resistance has also led to intense debates about whether individuals should be constructed as requiring care or personal support (for example, Thomas, 2007). However, as Dowse (2001) points out, the disability movement's promotion of a strong disabled identity may be difficult to achieve for people with LD. She acknowledges some people with LD will have cognitive limitations which curtail a broader awareness of the political voice expressed by other disabled people.

\section{Discussion}

This article has identified the historical rise of voluntarism in LD services in Ireland and then examined the geographical factors that have contributed to the uneven development of the sector across space. At a time when writers such as Salamon et al. (2003) are posing the global rise in the importance of voluntarism as a revolution, Ireland experienced the 'community turn' much earlier than 
most Western states, in that the state advocated a 'hands-off approach in LD services from the outset. Because of the legacy that subsidiarity left behind, the state's reluctance to interfere in family policy, and the impact of clientelism, the landscape of voluntarism in Ireland is quite distinctive.

The way in which voluntarism developed appears to have left a mark on contemporary policy for people with LD. First, the lasting imprint of Catholic ideology and discourse on older generations regarding the role of charity arguably could explain the much higher current rate of fundraising in Ireland. As was seen, this was actively encouraged in some parts of the country, where some regional HSEAs were committed to policies centred on their reluctance to develop public provision in favour of contracting out to the voluntary sector. This reflects similar findings from Regulska (1999) that the historical and political context of space highlights how differences in culture and socio-economic circumstances affect people's willingness and ability to support the development of local voluntarism. It also illustrates how differing histories of donation and philanthropic development within places contributes to a geographical unevenness in voluntary welfare that has less to do with contemporary need and more to do with local histories of philanthropy, and active 'champions' of LD causes (Bryson et al., 2002).

Despite the reform process being in full swing with the economic boom, there still remains a sustained attempt to incorporate the voluntary sector in LD service provision. The state's attention, in terms of direct provision, has been the introduction of some means-tested benefits and the establishment of more residential places. Unlike recent policy developments in the UK and the Netherlands emphasising individualism, such as individualised budgets and selfcare (Glendinning, 2006), familialism still remains dominant in Ireland, in terms of Irish state payments (such as the Carers Allowance, which is means-tested on the household) and the extent of person-centred care, which remains at the pilot stage or else formulated locally by voluntary body steering groups. Above all, the state appears content with oiling the machine by channelling resources at a local level to voluntary bodies, while at the same time remaining largely unaware of gaps in coverage.

At the local level, as a result of the close inter-dependencies between voluntary organisations and the state and the consequent interplay between politics, place and voluntarism, community care varies a lot regionally. This was evidenced by the lack of national planning of community care, differences in priorities across health regions, local clientelism, and the funding agreements with voluntary agencies. While it appears at the national scale that the sector exists as a central player with the state, in reality how LDV organisations are seen in relation to state provision seems to vary at the local level; some HSEAs see the sector as central to their community care landscape, whereas others view it as residual and subsidiary. Due to the lack of mandatory requirements, regional HSEAs typically 
reply to specific needs and are often determined by local political influence. Within this interplay, the impact of human agency can be seen to have a clear role in the creation of the specific geography of Irish care provision.

While voluntary-statutory relationships will almost certainly become more complex, the extent of grant funding and local political action will, however, continue to shape the sector, as a contrast to increasing regulation and 'heavy-handedness' elsewhere. While the benefits include increased flexibility, responsiveness and local advocacy, there are certain drawbacks: while UK policy is beginning to exhort localism, the evidence from Ireland suggests that it can lead to inconsistent responses to localised needs, service gaps, adoption of different stances by local providers, and sometimes tensions regarding agencies' versus the disability communities' philosophies.

This article has been concerned with identifying the importance of a geographical perspective in understanding the concept of voluntarism. It has used the learning disability voluntary sector in Ireland as a case study to show the significance of specific historical, cultural and political contexts in the development of its particular spatial form at both macro- and micro-scales. In doing so, it has attempted to show that a scalar approach which recognises the national, regional and local levels, where human agency also plays a significant role, is valuable in understanding the place-specific picture of the voluntary sector. Thus, while the landscape of voluntarism is in part shaped by structural factors, the characteristics of a place can offer important insights into the spatial distribution of voluntarism with implications for local access, service delivery and policy development.

\section{References}

Anheier, H. K. and Salamon, L. M. (1999), 'Volunteering in cross-national perspective: initial comparisons', Law and Contemporary Problems, 62: 4, 43-66.

Bacon, D. (2006), 'Faith-based organisations and welfare provision in Northern Ireland and North America: whose agenda?', in C. Milligan and D. Conradson (eds), Landscapes of Voluntarism: New Spaces of Health, Welfare and Governance, Bristol: Policy Press.

Barnett, P. and Barnett, R. (2006), 'New times, new relationships: mental health, primary care and public health', in C. Milligan and D. Conradson (eds), Landscapes of Voluntarism: New Spaces in Health, Welfare and Governance, Bristol: Policy Press.

Bondi, L. (2004), 'A double-edged sword? The professionalisation of counselling in the United Kingdom', Health and Place, 10: 319-28.

Breathnach (1992), 'The Sad Saga of Local Government Reform in Ireland', Paper presented at Conference on 'The State of the Irish Political System', Cork, May.

Brown, M. (1997), RePlacing Citizenship: AIDS Activism and Radical Democracy, London: Guilford Press.

Bryson, J., McGuinness, M. and Ford, R. (2002), 'Chasing a "loose and baggy monster": almshouses and the geography of charity', Area, 34: 48-58.

Central Statistics Office (2004), Disability and Carers, Dublin: Government of Ireland.

Cochrane, A. and Gerwitz, S. (2000), Comparing Welfare States, London: Sage.

Crosscare (2007), 'Who is Crosscare?', http://www.crosscare.ie/who_is_crosscare.htm, accessed 10 January 2008. 
Department of Health (1960), The Problem of the Mentally Handicapped, White Paper, Dublin: Stationery Office.

Department of Social Community and Family Affairs (DSCFA) (2000), Supporting Voluntary Activity: A Framework for Supporting Voluntary Activity and for Developing the Relationship between the State and the Community and Voluntary Sector, White Paper, Dublin: Stationery Office.

Disability Federation of Ireland (DFI) (2002), An Overview of Irish Health Legislation, Dublin: DFI.

Donnelly-Cox, G. and O'Regan, A. (1998), 'The Irish voluntary sector: a case-based exploration of organisational growth patterns and organisational dynamics, ISTR Conference', Université de Genève, Geneva, Switzerland, July.

Donnelly-Cox, G., Donoghue, F. and Hayes, T. (2001), 'Conceptualizing the third sector in Ireland, north and south', Voluntas: International Journal of Voluntary and Nonprofit Organizations, 12: 3, 195-204.

Donoghue, F. (1998), 'The politicisation of disadvantage in the Republic of Ireland: the role played by the third sector', ISTR Conference, Université de Genève, Geneva, Switzerland, July.

Donoghue, F. (2002), 'Reflecting the relationships: an exploration of the relationships between the former Eastern Health Board and the voluntary organisations in the Eastern Region', South-Western Area Health Board, Dublin.

Donoghue, F., Anheier, H. and Salamon, L. (1999), Uncovering the Non-profit Sector in Ireland: Its Economic Value and Significance, Baltimore: Johns Hopkins Institute for Policy Studies.

Dowse, L. (2001), 'Contesting practices, challenging codes: self advocacy, disability politics and the social model', Disability and Society, 16: 123-41.

Fernández, J-L., Kendall, J., Davey, V. and Knapp, M. (2007), 'Direct payments in England: factors linked to variations in local provision', Journal of Social Policy, 36: 97-121.

Gatrell, A. (2002), Geographies of Health: An Introduction, Oxford: Blackwell.

Geoghegan, M. and Powell, F. (2006), 'Community development, partnership governance and dilemmas of professionalization: profiling and assessing the Case of Ireland', British Journal of Social Work, 36: 845-61.

Glendinning, C. (2006), 'Paying family caregivers: evaluating different models', in C. Glendinning and P. Kemp (eds), Cash and Care, Bristol: The Policy Press.

Government of Ireland (1965), Commission of Inquiry on Mental Handicap, Dublin: Stationery Office.

Grønbjerg, K. A. and Paarlberg, L. (2001), 'Community variations in the size and scope of the nonprofit sector: theory and preliminary findings', Nonprofit and Voluntary Sector Quarterly, 30: 4, 684-706.

Haslett, D., Ruddle, H. and Hennessy, G. (1998), The Future Organisation of the Home Help Service in Ireland, Dublin: National Council on Ageing and Older People.

Kitchin, R. and Wilton, R. (2003), 'Disability activism and the politics of scale', The Canadian Geographer, 47: 2, 97-115.

Lalich, W. F. (2006), 'Developing voluntary community spaces and ethnicity in Sydney, Australia', in C. Milligan and D. Conradson (eds), Landscapes of Voluntarism: New Spaces of Health, Welfare and Governance, Bristol: Policy Press.

Mackintosh, M. (2000), 'Flexible contracting? Economic cultures and implicit contracts in social care', Journal of Social Policy, 29: 1-19.

Macmillan, R. and Townsend, A. (2006), 'A "new institutional fix"? The "community turn" and the changing role of the voluntary sector', in C. Milligan and D. Conradson (eds), Landscapes of Voluntarism: New Spaces of Health, Welfare and Governance, Bristol: The Policy Press.

McLaughlin, E. (1993), 'Ireland: Catholic corporatism', in A. Cochrane and J. Clarke (eds), Comparing Welfare States: Britain in International Context, London: Open University Press. 
Meade, R. (2005), 'We hate it here, please let us stay! Irish social partnership and the community/voluntary sector's conflicted experiences of recognition', Critical Social Policy, 25: 3, 349-73.

Milligan, C. (2001), Geographies of Care: Space, Place and the Voluntary Sector, Ashgate: Aldershot.

Milligan, C. (2007), 'Geographies of voluntarism: mapping the terrain', Geography Compass, 1: 2, 183-99.

Milligan, C. and Fyfe, N. R. (2004), 'Putting the voluntary sector in its place: geographical perspectives in voluntary activity and social welfare in Glasgow', Journal of Social Policy, 33: 73-93.

NAMHI (2003), Directory of Services for People with an Intellectual Disability, Dublin: NAMHI.

NAMHI (2004), 'Homepage', http://www.namhi.ie/namfr/namfnl.htm, accessed 23 February, 2004.

O'Leary, D. (2000), Vocationalism and Social Catholicism in Twentieth-Century Ireland, Dublin: Irish Academic Press.

Oliver, M. and Barnes, C. (1998), Disabled People and Social Policy: From Exclusion to Inclusion, London: Longman.

Pfau-Effinger, B. (2005), 'Culture and welfare state policies: reflections on a complex interrelation', Journal of Social Policy, 34: 3-20.

Powell, F. W. and Guerin, D. (1997), Civil Society and Social Policy: Voluntarism in Ireland, Dublin: A. A. Farmar.

Quin, S. and Redmond, B. (1996), 'Moving from needs to rights: social policy for people with disability in Ireland', in S. Quin, P. Kennedy, A. O'Donnell and K. Gabriel (eds), Contemporary Irish Social Policy, Dublin: University College Dublin Press.

Regulska, J. (1999), 'NGOs and their vulnerabilities during the time of transition: the case of Poland', International Journal of Voluntary and Nonprofit Organizations, 10: 61-71.

Salamon, L. M., Anheier, H. K. and associates (1998), The Emerging Sector Revisited, Baltimore: Johns Hopkins Institute for Policy Studies.

Salamon, L. M., Sokolowski, S. W. and List, R. (2003), Global Civil Society: An Overview, Baltimore: Johns Hopkins Institute for Policy Studies, Centre for Civil Society Studies.

Sherman, A. L. (2000), The Growing Impact of Charitable Choice: A Catalogue of New Collaborations between Government and Faith-based Organizations in Nine States, Washington DC: Center for Public Justice.

Taylor, M. and Bassi, A. (1998), 'Unpacking the state: the implications for the third sector of changing relationships between national and local government', Voluntas, 9: 2, 113-36.

Thomas, C. (2007), Sociologies of Disability and Illness: Contested Ideas in Disability Studies and Medical Sociology, Basingstoke: Palgrave Macmillan.

Vincent, J. and Harrow, J. (2005), 'Comparing thistles and roses: the application of governmental-voluntary sector relations theory to Scotland and England', Voluntas, 16: 4, 375-95.

Walsh, T. (1999), 'Changing expectations: the impact of child 'protection' on Irish social work', Child and Family Social Work, 4: 33-44.

Wolch, J. R. (1989), 'The Shadow State: transformations in the voluntary sector', in J. R. Wolch and M. Dear (eds), The Power of Geography: How Territory Shapes Social Life, Boston: Unwin Hyman.

Wolch, J. R. (2006), 'Forward: beyond the shadow state?', in C. Milligan and D. Conradson (eds), Landscapes of Voluntarism: New Spaces of Health, Welfare and Governance, Bristol: Policy Press.

Wyatt, M. (2002), 'Partnership in health and social care: the implications of government guidance in the 1990s in England with particular reference to voluntary organisations', Policy and Politics, 30: 2, 167-82. 